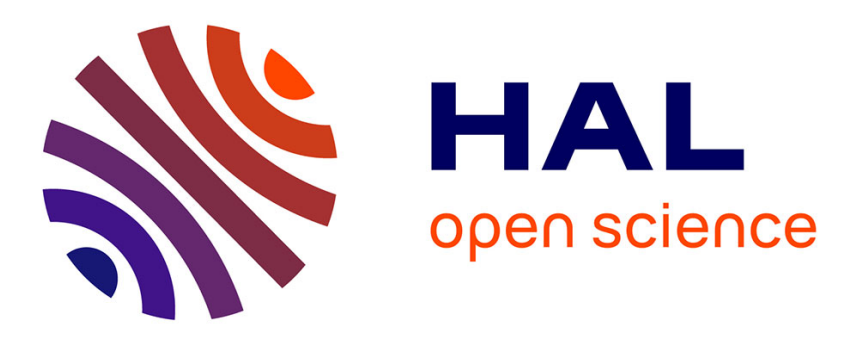

\title{
Physico-chemical-mechanical and in vitro biological properties of calcium phosphate cements with doped amorphous calcium phosphates.
}

Marion Julien, Ibrahim Khairoun, Racquel Z. Legeros, Séverine Delplace, Paul Pilet, Pierre Weiss, Guy Daculsi, Jean-Michel Bouler, Jérôme Guicheux

\section{To cite this version:}

Marion Julien, Ibrahim Khairoun, Racquel Z. Legeros, Séverine Delplace, Paul Pilet, et al.. Physico-chemical-mechanical and in vitro biological properties of calcium phosphate cements with doped amorphous calcium phosphates.. Biomaterials, 2007, 28 (6), pp.956-65. 10.1016/j.biomaterials.2006.10.018 . inserm-00170245

\section{HAL Id: inserm-00170245 https://www.hal.inserm.fr/inserm-00170245}

Submitted on 7 Sep 2007

HAL is a multi-disciplinary open access archive for the deposit and dissemination of scientific research documents, whether they are published or not. The documents may come from teaching and research institutions in France or abroad, or from public or private research centers.
L'archive ouverte pluridisciplinaire HAL, est destinée au dépôt et à la diffusion de documents scientifiques de niveau recherche, publiés ou non, émanant des établissements d'enseignement et de recherche français ou étrangers, des laboratoires publics ou privés. 


\title{
Physico-chemical and in vitro biological properties of novel doped amorphous calcium
} phosphate-based cements.

M. Julien ${ }^{1 \#}$, I. Khairoun ${ }^{1 \#}$, S. Delplace ${ }^{1}$, P. Pilet ${ }^{1}$, RZ. LeGeros ${ }^{2}$, P. Weiss ${ }^{1}$, JM. Bouler $^{1}$, J. Guicheux ${ }^{1}$

\footnotetext{
${ }^{1}$ Inserm, UMRS 791,Laboratoire d'Ingénierie Ostéo-articulaire et Dentaire, LIOAD, Nantes, France ; Univ Nantes, Faculté de Chirurgie Dentaire, F-44042 Nantes, France

${ }^{2}$ Department of Biomaterials and Biomimetics, New York University College of Dentistry, 345 East 24th Street, New York, NY 10010, USA

\# Both authors contributed equally to this work.

* Corresponding author: Jean Michel Bouler
}

\begin{abstract}
Calcium phosphate cements (CPC) are successfully used as bone substitutes in dentistry and orthopaedic applications. Doped amorphous CPC cements with various ions $\mathrm{Mg}, \mathrm{Zn}$ and F were investigated in an attempt to improve their physicochemical and biological properties. The cement samples were composed of a settable matrix and biphasic calcium phosphates (BCP) granules. X-ray diffraction data of the cement matrices after $24 \mathrm{H}$ setting revealed apatite with poor crystallinity, whereas BCP granules did not react. Samples doped with F showed shorter setting times and greater compressive strength in comparison to those doped with $\mathrm{Mg}$ or $\mathrm{Zn}$. In contrast, porosity data showed that the total porosity of $\mathrm{Mg}$ doped samples was greater compared to samples doped with Zn and F. Scanning electron microscopy (SEM) revealed that the crystals produced after setting reaction were poorly crystalline consisting of petal-like crystals. Those of Mg doped samples look smaller and finer. SEM observations and measurement of mitochondrial activity (MTS assay) indicated that the MC3T3-E1 cells remained viable in contact with the various materials. In addition, the results indicate that MC3T3-E1 cells maintained their
\end{abstract}


capability to express ALP on the various materials. These overall results indicate that these materials are good candidates for bone substitutions.

Keywords: Calcium phosphate cements; Dopant; Osteoblasts; Biocompatibility

\section{Introduction}

The principal advantages of calcium phosphate materials include: similarity in composition to the bone mineral, bioactivity, osteoconductivity and ability to form a uniquely strong interface with bone (1). Calcium phosphate materials are available as granules, blocks, coatings on dental and medical implants, and as cements.

The concept of apatitic calcium phosphate cements (CPC) was first introduced by LeGeros in 1982 (2) and the first patent on self-setting CPC was obtained by Brown and Chow in 1983 (3). Currently, several CPC with varying compositions of the powder and liquid components are commercially available and many more are in experimental stages (4-10).Unlike the calcium phosphate bioceramics in granules or pre-shaped form, CPC has the major advantage of being able to readily adapt to the shape of the bone defect, rapidly integrate into the bone structure and be transformed into new bone (8-10) by the cellular action of bone cells (osteoclasts and osteoblasts) responsible for the local bone remodelling (11-14). However, in spite of these optimal properties, CPCs have limitations due to their poor mechanical properties and low in vivo biodegradation. Because of the absence of macroporosity that will allow cell colonisation and tissue ingrowth, the current commercial CPCs remain dense after implantation. To overcome these problems we sought to decipher whether doping amorphous based CPC with small amounts of ions like $\mathrm{Mg}$, Zn or F may improve their physico chemical and biological properties. 
A CPC formulation incorporating stabilised amorphous calcium phosphate (ACP) and biphasic calcium phosphate (BCP) ceramic was therefore recently developed (15). The BCP consisted of hydroxyapatite (HA) and beta-tricalcium phosphate ( $\beta$-TCP).

ACP can be made more or less stable (i.e., more or less soluble or more or less susceptible to convert into other calcium phosphates) depending on the amount and ions incorporated. In order to stabilise ACP we incorporated ions. The prevention of ACP transformation will increase its in vivo dissolution properties which in turn will provide macroporosity in the cement matrix allowing cell colonization and tissue ingrowth.

In view of the above mentioned data, the main objectives of the present study were i) to synthesise and determine the physico-chemical properties of $\mathrm{Mg}, \mathrm{Zn}$ and $\mathrm{F}$ doped ACP based cements and ii) to assess the effect of such calcium phosphate cements on in vitro osteoblastic behaviour. In this attempt we synthesised $\mathrm{Mg}, \mathrm{Zn}$ and F doped ACP based cements, and we evaluated their chemical properties (XRD and FTIR), setting times, porosity and compressive strength. Then the cytocompatibility of such materials was evaluated by examining the morphology, viability and alkaline phosphatase (ALP) activity of osteoblastic MC3T3-E1 cells cultured in contact with doped materials. 


\section{Materials and methods}

\subsection{Cement preparation}

The powder components of the cement included: BCP ceramic granules, $\alpha-\mathrm{TCP}$, monocalcium phosphate monohydrate (MCPM) and ACP incorporating carbonate (ACCP), with magnesium (Mg-ACCP), with zinc (Zn-ACCP) or with fluoride (F-ACCP) ions. The BCP consisted of an intimate mixture of $60 \% \mathrm{HA}$ and $40 \% \beta$-TCP. A sieved fraction of BCP granules with diameters ranging from 80 to $200 \mu \mathrm{m}$ was selected. $\alpha$-TCP was prepared by heating an appropriate mixture of dicalcium phosphate $\mathrm{CaHPO}_{4}$ and $\mathrm{CaCO}_{3}$ for 6 hours at $1300{ }^{\circ} \mathrm{C}$, and quenching it in air down to room temperature. The amorphous calcium phosphate salts (ACP) were prepared by double decomposition of mixed aqueous solutions of soluble calcium and phosphate salts as previously described (Ref. 15). The precipitate formed was immediately filtered and lyophilised during $24 \mathrm{~h}$. The molar ratio of $\mathrm{Mg} / \mathrm{Ca}, \mathrm{Zn} / \mathrm{Ca}$ and $\mathrm{F} / \mathrm{PO}_{4}$ was the same for all $\mathrm{ACP}$ preparations. The chemical composition of the cement powder consisted in a settable matrix ( $\alpha-\mathrm{TCP}, \mathrm{MCPM}$, $\mathrm{ACP})$ with a main diameter of $15 \mu \mathrm{m}$ and $\mathrm{BCP}$ granules. The cement consisted of $70 \mathrm{wt} \%$ matrix and $30 \mathrm{wt} \%$ BCP. Samples of the three materials tested were denoted as follows: Mg-BCP for the formulation mixed with $\mathrm{Mg}-\mathrm{ACCP}, \mathrm{Zn}-\mathrm{BCP}$ for the formulation mixed with $\mathrm{Zn}-\mathrm{ACCP}$, and F-BCP for the formulation mixed with F-ACCP. Powder and liquid were mixed in a mortar for about $1 \mathrm{~min}$. The cement samples were prepared at a liquid/powder ratio (L/P) of $0.36 \mathrm{ml} / \mathrm{g}$ and the liquid used was 3 wt $\% \mathrm{Na}_{2} \mathrm{HPO}_{4}$ in distilled water. For cell culture experiments, cement powders were pressed into discs with a diameter of $13 \mathrm{~mm}$. The discs were then sterilised by steam for $30 \mathrm{~min}$ at $121^{\circ} \mathrm{C}$.

\subsection{Chemical analysis}


The set samples and raw materials were manually crushed to a fine powder in an agate mortar for $\mathrm{x}$-ray diffraction (XRD) analysis. The XRD patterns were recorded by step scanning using a microprocessor-controlled diffractometer system (Philips PW 1830) with Ni-filtered copper $\mathrm{K}_{\alpha}$ generated at $40 \mathrm{kV}$ and $30 \mathrm{~mA}$. The data were collected in a continuous scan mode. The step scanning was performed with an integration time of $3 \mathrm{sec}$ at intervals of $0.05^{\circ}(2 \theta)$.

Fourier transform infrared (FTIR) spectroscopy (Magna IR 500; Nicolet) was used to characterise the lyophilised ACP. Samples were ground in $\mathrm{KBr}$ to ensure homogeneity and pressed to form a sample pellet.

The study of the morphology evolution of the crystalline structures that are formed during the process of cement setting was carried out by examining the fractured surfaces of samples by scanning electron microscopy (LEO $1450 \mathrm{VP})$.

\subsection{Setting times}

Initial (I) and final (F) setting times were determined according to the C266-ASTM standard. The light and thick needle is used to measure the initial setting time, the heavy and thin needle for the final setting time.

\subsection{Compressive strength and porosity}

Cylindrical specimens, $12 \mathrm{~mm}$ high and $6 \mathrm{~mm}$ in diameter, were prepared and stored for $24 \mathrm{~h}$ in saline solution at $37^{\circ} \mathrm{C}$. The hardened specimens were removed from the moulds prior to determination of the compressive strength and porosity measurements. The compressive strength was determined using a TA.HDplus Texture Analyser. Mercury porosimetry has been used as the main method for porosity measurements, the experiments were carried out in a Porosimeter AutoPore III 9420. 


\subsection{Cell culture}

MC3T3-E1 cells are a non-transformed cell line established from newborn mouse calvaria and exhibit an osteoblastic phenotype (16). Cells were routinely grown in $\alpha$-MEM medium supplemented with $10 \%$ FCS, $1 \%$ penicillin/streptomycin and $1 \%$ L-Glutamine. Cells were subcultured once a week using Trypsin/EDTA and maintained at $37{ }^{\circ} \mathrm{C}$ in a humidified atmosphere of $5 \% \mathrm{CO}_{2}$ in air. Fresh medium was added every two days.

\subsection{Cell morphology}

MC3T3-E1 cell morphology was studied in contact with the various material discs by Scanning Electron Microscopy (SEM). Cells were seeded either onto Mg-BCP, Zn-BCP and F-BCP discs or onto glass coverslips (positive control) in 24-mutiwell plates at a final density of 10000 cells $/ \mathrm{cm}^{2}$. After indicated times, media were removed and specimens were fixed with $4 \%$ glutaraldehyde in PBS (pH 7.2) for $1 \mathrm{~h} 30 \mathrm{~min}$ at $4{ }^{\circ} \mathrm{C}$. After dehydratation in graded alcohols, specimens were treated with graded mixture of ethanol/trichlorotrifluoroethane $(75 / 25,50 / 50$, 25/75 and 0/100). They were then sputter-coated with gold palladium. The surface of the specimens was finally examined with backscattered (BSE) and secondary electrons in SEM under $15 \mathrm{kV}(17)$.

\subsection{Cell viability}

Cell viability was measured as mitochondrial NADH/NADPH-dependent dehydrogenase activity, resulting in the cellular conversion of the tetrazolium salt MTS into a soluble formazan dye (18, 19) with the CellTiter 96 Aqueous non-radioactive cell proliferation assay (Promega). MC3T3E1 cells were cultured either onto $\mathrm{Mg}-\mathrm{BCP}, \mathrm{Zn}-\mathrm{BCP}$ and F-BCP discs or in the absence of material (Plastic) in 24 multiwell plates at a density of 10000 cells $/ \mathrm{cm}^{2}$. After indicated times, 
culture media were removed and $100 \mu \mathrm{l}$ of MTS solution was added in each well for $2-3 \mathrm{~h}$ according to the manufacturer's instructions. Finally, colorimetric measurement of formazan dye was performed on a spectrophotometer with an optical density reading at $490 \mathrm{~nm}$. Results were expressed as a relative MTS activity as compared to control conditions (Plastic).

\subsection{Alkaline phosphatase (ALP) activity}

ALP activity was evaluated, as previously described (Ref.20) in MC3T3-E1 cells cultured either onto $\mathrm{Mg}-\mathrm{BCP}, \mathrm{Zn}-\mathrm{BCP}$ and F-BCP discs or in the absence of material (Plastic) in 24 multiwell plates $\left(10000\right.$ cells $\left./ \mathrm{cm}^{2}\right)$. After indicated times, cells were washed twice with ice-cold PBS and scraped in a $0.2 \%$ aqueous solution of Nonidet P-40. Cell suspension was then sonicated on ice for $30 \mathrm{~s}$ and centrifuged for $5 \mathrm{~min}$ at $4^{\circ} \mathrm{C}$. Aliquots of supernatants were subjected to protein assay with the Pierce Coomassie Plus assay reagent and to ALP activity measurement. ALP activity was assessed at $\mathrm{pH} 10.3$ in $0.1 \mathrm{M}$ 2-amino-2-methyl-1-propanol containing $1 \mathrm{mM} \mathrm{MgCl}$. P-NPP (10 mM) was used as a chromogenic substrate for an optical density reading at $405 \mathrm{~nm}$. Results were expressed as relative ALP activity compared with control conditions (Plastic).

\subsection{Statistical analysis}

Each experiment was conducted in triplicate and repeated at least twice with similar results. Results are expressed as mean +/- SEM of triplicate determinations. Comparative studies of means were performed using one-way ANOVA followed by a post hoc test (Fisher projected least significant difference) with a statistical significance at $p<0.05$. 


\section{Results}

\subsection{Chemical characterisation}

The XRD patterns of the various ACP preparations containing $\mathrm{Mg}, \mathrm{Zn}$ and $\mathrm{F}$ showed a high background and absence of any diffraction peaks (Fig. 1a). FTIR spectra (Fig. 1b) of the freezedried ACP preparations showed the absorption bands for $\mathrm{CO}_{3}$ groups (at 1420 to1450 $\mathrm{cm}^{-1} ; 970$ to $980 \mathrm{~cm}^{-1}$ ) and for $\mathrm{PO}_{4}$ groups (at 950 to $1200 \mathrm{~cm}^{-1}$ and 450 to $650 \mathrm{~cm}^{-1}$ ). The lack of resolution of the $\mathrm{PO}_{4}$ absorption bands is characteristic of ACP salts. These data unequivocally indicate that our ACP preparations were amorphous whatever the ion used.

The XRD data give similar results for the three cement samples. As a representative pattern, the evolution of the cement samples containing Mg during its setting is reported. XRD patterns of the cements obtained after $24 \mathrm{~h}$ ageing were similar and revealed that the BCP granules did not react when the matrix fully transformed to apatite with poor crystallinity (Fig. 2).

As shown in SEM pictures (Fig. 3), the three cement samples after 24h ageing in saline solution at $37^{\circ} \mathrm{C}$ displayed a typical fine apatite microstructure. It is observed that the crystals produced by the setting reaction are poorly crystalline consisting of petal-like crystals. The Mg-BCP formed crystals look smaller and finer than Zn-BCP or F-BCP.

\subsection{Setting times}

The values obtained for the initial setting time (I) and the final setting time (F) for the cement samples prepared at room temperature are given in Table 1. Samples doped with F ions set faster than those doped with $\mathrm{Zn}$ or $\mathrm{Mg}$. It appears that for all samples, the setting times remain clinically reasonable.

\subsection{Compressive strength and porosity}


The data of compressive strength and total porosity of cement samples after $24 \mathrm{H}$ setting in saline solution at $37{ }^{\circ} \mathrm{C}$ are given in Table 2. Samples doped with $\mathrm{F}$ ions show a significant increase in comparison with those doped with $\mathrm{Mg}$ or $\mathrm{Zn}$. The CS values are slightly different between $\mathrm{Mg}$ $\mathrm{BCP}$ and $\mathrm{Zn}-\mathrm{BCP}$ samples. In contrast, porosity data showed that the total porosity of $\mathrm{Mg}-\mathrm{BCP}$ samples is greater compared to $\mathrm{Zn}-\mathrm{BCP}$ and F-BCP samples, in addition not only the porosity is greater, but also the percentage of macrospores is greater. The cement samples doped with $\mathrm{Mg}$, $\mathrm{Zn}$ and $\mathrm{F}$ showed respectively a total porosity of $66 \%, 60 \%$ and $51 \%$ where presence of macroporosity was evident. Pore size distribution revealed that $\mathrm{Mg}-\mathrm{BCP}$ samples contained about $22 \%$ macrospores, $14 \%$ for $\mathrm{Zn}-\mathrm{BCP}$ and $8 \%$ for F-BCP samples.

\subsection{Cell morphology}

Scanning electron microscopic examinations of osteoblastic MC3T3-E1 cells on materials show that cells cultured for $48 \mathrm{~h}$ were capable of adhering onto $\mathrm{Mg}-\mathrm{BCP}, \mathrm{Zn}-\mathrm{BCP}$ and F-BCP discs (Figure 4). Qualitative comparison of the three materials to the positive control reveals a higher cell density on the surface of glass cover slips than onto cement materials doped with $\mathrm{Mg}, \mathrm{Zn}$ or F ions. Equivalent amount of cells however, was observed on the surface of the three materials (Fig. 4 and low magnification on the left panels). Cell morphology was also examined at higher magnification (Figure 3 and right panels). MC3T3-E1 cells displayed flattened and elongated morphology whatever the material. In addition, cells exhibited numerous cytoplasmic extensions and lamellopodia. These results suggest no adverse cellular response to materials doped with $\mathrm{Mg}$, Zn or F ions.

\subsection{Cell viability}


To examine the viability of osteoblastic cells we aimed at determining whether the MTS activity was influenced by the various materials in MC3T3-E1 cells. Cells were cultured either onto MgBCP, Zn-BCP and F-BCP discs or directly on plastic (control). MTS activity was measured at 7, 14 and 21 days following initiation of the cell/materials interactions. Results show that cell viability was decreased after 7 days in culture (Figure 4). The MTS activity of osteoblasts cultured onto the various materials discs was significantly reduced $(\mathrm{p}<0.05)$ by about $73 \%$ for Mg-BCP and $64 \%$ for Zn-BCP and F-BCP as compared to plastic conditions (Figure 4). After 14 days in culture, MC3T3-E1 cells showed an increase in cell viability. Indeed, the reduction of MTS activity was about $45 \%$ for Mg-BCP and F-BCP as compared to control conditions. Cell viability of MC3T3-E1 cells grown on Zn-BCP was no more statistically different from cells grown on plastic after 14 days in culture. After three weeks in culture, cell viability of osteoblasts cultured onto the various cement discs was not statistically different from that observed in control conditions (Fig. 4).

These results reveal that osteoblast viability decreased the first two weeks in culture onto $\mathrm{Mg}$ BCP and F-BCP discs. This reduction was however completely abolished after three weeks in culture. $\mathrm{Zn}$-BCP cement seems to have less influence on cell viability since a reduction was observed the first week only.

\subsection{ALP activity}

To further analyze the osteoblastic behaviour we performed a measurement of ALP activity in MC3T3-E1 cells cultured onto the various cements discs for 21 days. ALP activity was evaluated in osteoblasts seeded in direct contact with $\mathrm{Mg}-\mathrm{BCP}, \mathrm{Zn}-\mathrm{BCP}$ and F-BCP. The results indicated no significant decrease in ALP activity of osteoblasts interacting with cement discs as compared 
to plastic conditions (Fig. 5). These results indicate that MC3T3-E1 cells maintained their capability to express ALP on the various cement discs. 


\section{Discussion}

Calcium phosphate cements consist of a powder and an aqueous solution. They are prepared by dissolution and precipitation phenomenon. The precipitate is a conglomerate of crystals. After setting they remain dense and do not provide a rapid bone repair. The purpose of our work was to improve their physico chemical and biological properties by doping with small amounts of ions like $\mathrm{Mg}, \mathrm{Zn}$ or $\mathrm{F}$.

In this study, the three materials investigated consisted in a settable matrix ( $\alpha$-TCP, MCPM, doped ACP) and BCP granules. The ACP's used in these experimental materials were synthesized with $\mathrm{Mg}, \mathrm{Zn}$, or F ions to stabilise them for the purpose to prevent their conversion upon mixing with aqueous solution (20) and to investigate their combination with other calcium phosphate salts like $\alpha$-TCP or BCP on the physicochemical and biological properties of these materials. Early studies showed that some ions inhibit the crystallization of apatite and promote the formation of ACP. These ions include: $\mathrm{Mg}, \mathrm{Zn}, \mathrm{CO}_{3}$ and $\mathrm{P}_{2} \mathrm{O}_{5}(21,22)$. Studies have also shown that the transformation of ACP to other types of calcium phosphates (e.g., to apatite or dicalcium phosphate dehydrate) could be inhibited by the presence of some ions or molecules, e.g. $\mathrm{Mg}$ and $\mathrm{P}_{2} \mathrm{O}_{7}(22)$.

Previous studies $(23,24)$ dealing with the process of hydration of a cement based on $\alpha$-TCP$\mathrm{CaHPO}_{4}$ and a cement consisted of $\alpha$-TCP, $\beta$-TCP and $2 \%$ HA, reported that the $\beta$-TCP and $\mathrm{CaHPO}_{4}$ did not react and concluded that the responsible of the setting reaction is the $\alpha$-TCP. Apatite is the final product of the setting reaction in several $\alpha$-TCP based cement systems (5) and the mechanism of setting is an entanglement of precipitated crystals as described for gypsum (25). In our case, the cement matrix setting was the result of the $\alpha$-TCP hydrolysis giving as a product apatite plus traces of $\mathrm{ACP}$ depending on the doping ion ( $\mathrm{Mg}, \mathrm{Zn}$ or $\mathrm{F})$. This phenomenon 
could be evidenced by the presence of the different crystalline networks which are evolved in the setting reaction.

SEM pictures of samples doped with $\mathrm{Mg}$ indicated that the crystallites are much smaller than those of $\mathrm{Zn}$ or $\mathrm{F}$. This may indicate that the end product is apatite containing larger amounts of ACP. Conversely, the crystallites observed with samples doped with F were larger suggesting that the cement matrix was transformed to apatite.

In addition, in an attempt to determine whether our cements are in compliance with clinical requirements or not, we proposed to determine the setting times according to the C266-ASTM standard, the compressive strength according to F451-86 ASTM standard and the porosity.

F-BCP samples showed reduced setting times, greater compressive strength and lower porosity compared to $\mathrm{Zn}-\mathrm{BCP}$ and $\mathrm{Mg}$-BCP samples. In a previous study (26), the $\mathrm{CPC}$ containing more apatite seeds appeared to enhance the setting reaction thereby reducing the setting times and increase compressive strength. Lower compressive strength at the initial stages of the setting, as a result of ACP content in the end product, is compatible with a finer crystalline microstructure (case of $\mathrm{Mg}-\mathrm{BCP}$ ) and with a reduced interfacial strength of the contact points developed between crystals. Porosity data are correlated with compressive strength values. When the porosity increases, the compressive strength decreases as a result of the pore percentage present in the cement structure. Mg-BCP samples had greater total porosity and lower compressive strength. Taken together, data obtained in the present study show that the F ions stabilise less the $\mathrm{ACP}$ than $\mathrm{Zn}$ and $\mathrm{Mg}$ ions providing a full transformation of matrix to apatite.

Calcium phosphate biomaterials are biocompatible because the main mineral component of bone carbonated hydroxyapatite (27), is composed principally of calcium and phosphate ions. Reported biocompatibility of various calcium phosphate cements $(28,29)$ is attributed to either the 
biocompatibility of their individual ingredients ( $\alpha$-TCP, $\beta$-TCP, HA, brushite, monetite, ACP) or the biocompatibility of the setting reaction product (generally calcium-deficient apatite or carbonated hydroxyapatite).

In an attempt to determine the in vitro biological properties of our novel doped amorphous calcium phosphate-based cements, we were interested in determining the cytocompatibility of our materials according to standards (ISO 10993-5: Biological evaluation of medical devices - Part 5: Tests for in vitro cytotoxicity). We focused on morphology, cell viability and cell activity assays by direct contact with osteoblasts as target cells for any medical device intended for implantation in bony site. Among the cellular models of osteoblastic differentiation, MC3T3-E1 cell line is a non-transformed model derived from mouse calvaria that exhibit high sensitivity to cytotoxic signal (16). In a first set of experiments, we examined the morphology of MC3T3-E1 cells cultured in contact with discs of the various materials. Cells on the surface of materials were largely spread out and exhibited large cytoplasmic extensions suggesting an active cell migration. In addition, osteoblasts expanded on materials exhibit large pseudopodia thus strongly suggesting quite adhesion capabilities. For all tested materials, the chemical nature of the surface is likely to provide specific sites for focal adhesion molecules, thus allowing the cells to adhere (30). The molecules present at the focal adhesion contacts have recently been identified. These molecules have been shown to interact with transcription factors thereby controlling the expression of specific genes in target cells (31). Whether the surface of doped ACP-based cements may be able to activate the transcription of specific osteoblastic genes remains however to be further investigated.

To assess the effect of $\mathrm{Mg}, \mathrm{Zn}$ and $\mathrm{F}$ ions in $\mathrm{CPC}$ on cellular viability, we sought to evaluate the mitochondrial activity of osteoblasts. When the cells were cultured for short period of time, MTS 
activity was down-regulated, strongly suggesting alteration in cellular viability. Interestingly, this alteration remains transient and was totally recovered when cells were cultured in longer-term culture. One explanation to this temporary alteration could be the osteoblastic sensitivity to the material surface morphology or composition (32). To distinguish between both hypotheses, the specific effects of $\mathrm{Mg}, \mathrm{Zn}$ and $\mathrm{F}$ ions on osteoblastic viability and proliferation will deserve major consideration.

While the effects of surface materials remain a large matter of debate particularly with respect to the expression of osteoblastic phenotype $(33,34)$, we investigated whether MC3T3-E1 cells conserved their phenotype when cultured in contact with our various cements. Numerous osteoblastic markers have been described including transcription factors (osterix, Osf2/cbfa-1) and mineralization-regulatory proteins (osteocalcin, osteopontin, alkaline phosphatase...) (35). Since MC3T3-E1 cells express all these major osteoblastic hallmarks and particularly exhibit a high ALP activity in the confluent state, we analysed the enzymatic activity of ALP. Osteoblasts cultured onto the various cements showed lower but not significant ALP activity in comparison to control conditions. Despite the absence of effects for the various doped cements, it could be interesting to study the influence of $\mathrm{Mg}, \mathrm{Zn}$, and $\mathrm{F}$ ions on the activation of osteoblastic transcription factors.

In conclusion, doping CPC cements with $\mathrm{Mg}, \mathrm{Zn}$ or $\mathrm{F}$ ions was found to influence the dissolution of matrix, not only retarding or accelerating the setting process, but also influencing the precipitation of the apatite crystallites. Cement samples doped with $\mathrm{F}$ had shorter setting times, greater compressive strength and lower porosity than those doped with $\mathrm{Mg}$ or $\mathrm{Zn}$. In addition, these doped cement failed to affect the osteoblastic morphology, viability and activity. Today, to 
decipher the efficacy of such materials in bone repair, implantations in appropriate animal models of critical size defects are under investigation.

\section{$\underline{\text { Acknowledgements }}$}

This work was supported by Fondation Avenir pour la Recherche Médicale appliquée, études ET2-321 et ET5-405.

Marion Julien received a fellowship from INSERM and Région des Pays de la Loire. 


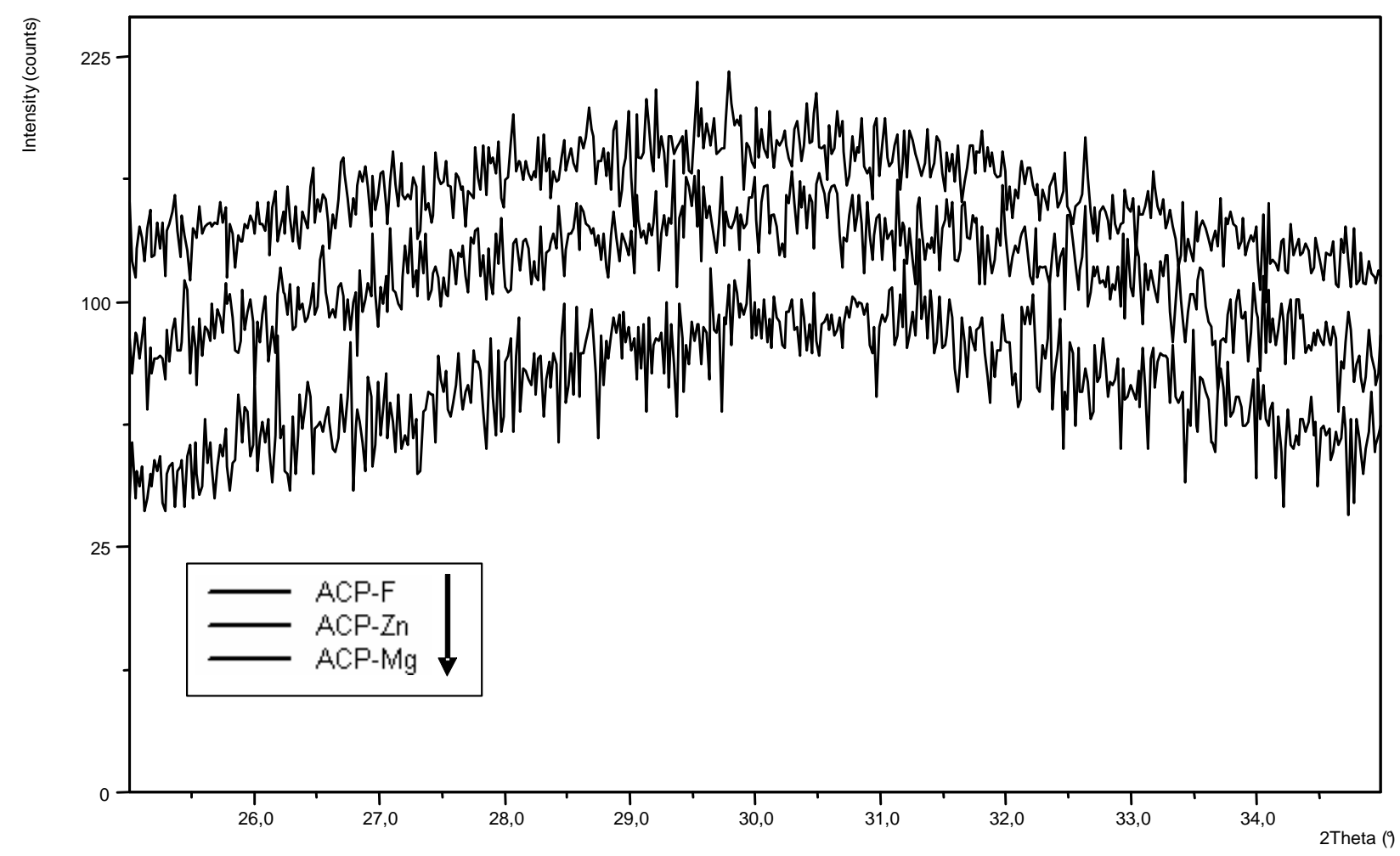

Figure 1(a) X-ray diffraction pattern of different amorphous calcium phosphate salts 
Figure 1(b)

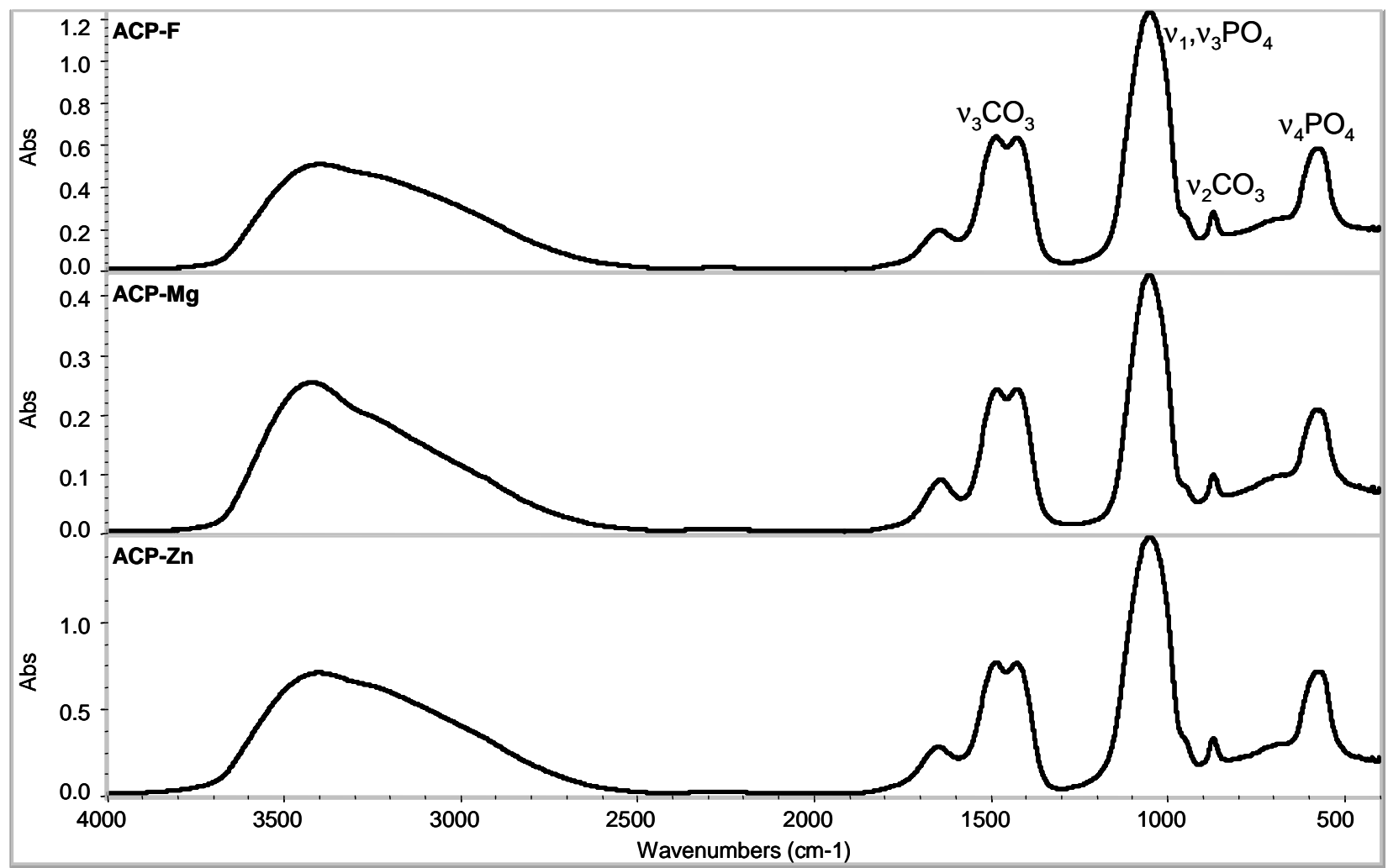


Figure 2

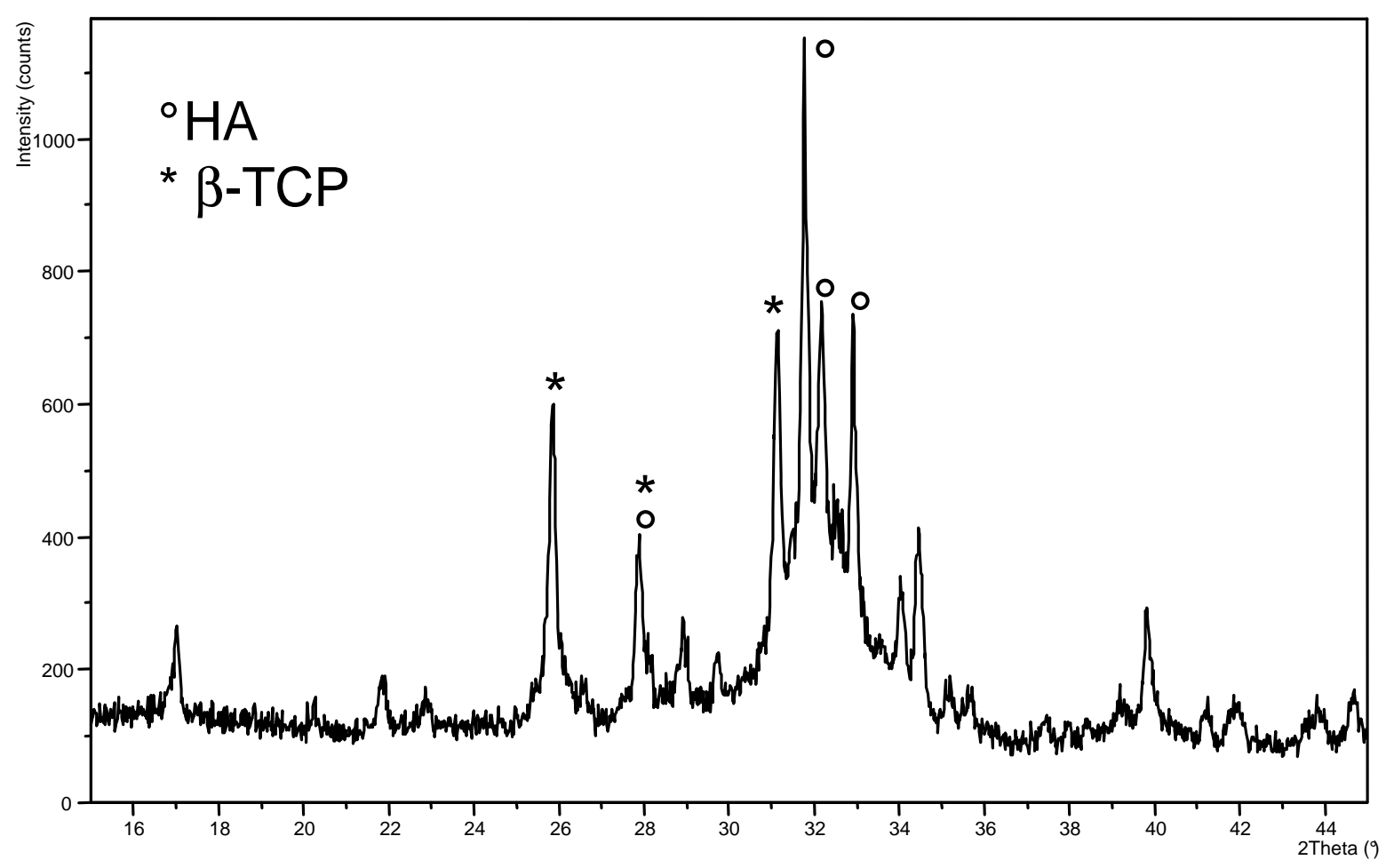


Figure. 3
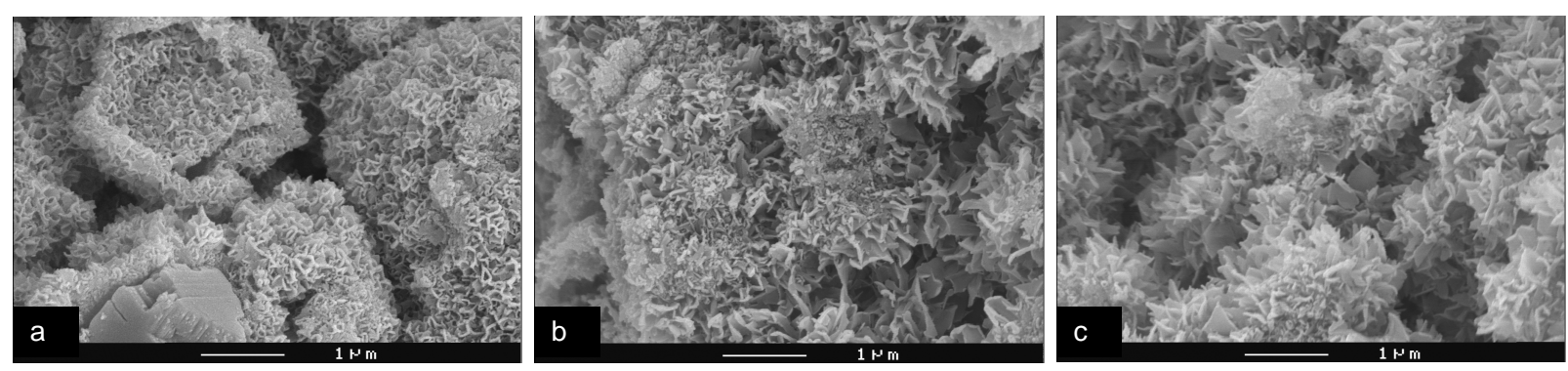
Figure 4.

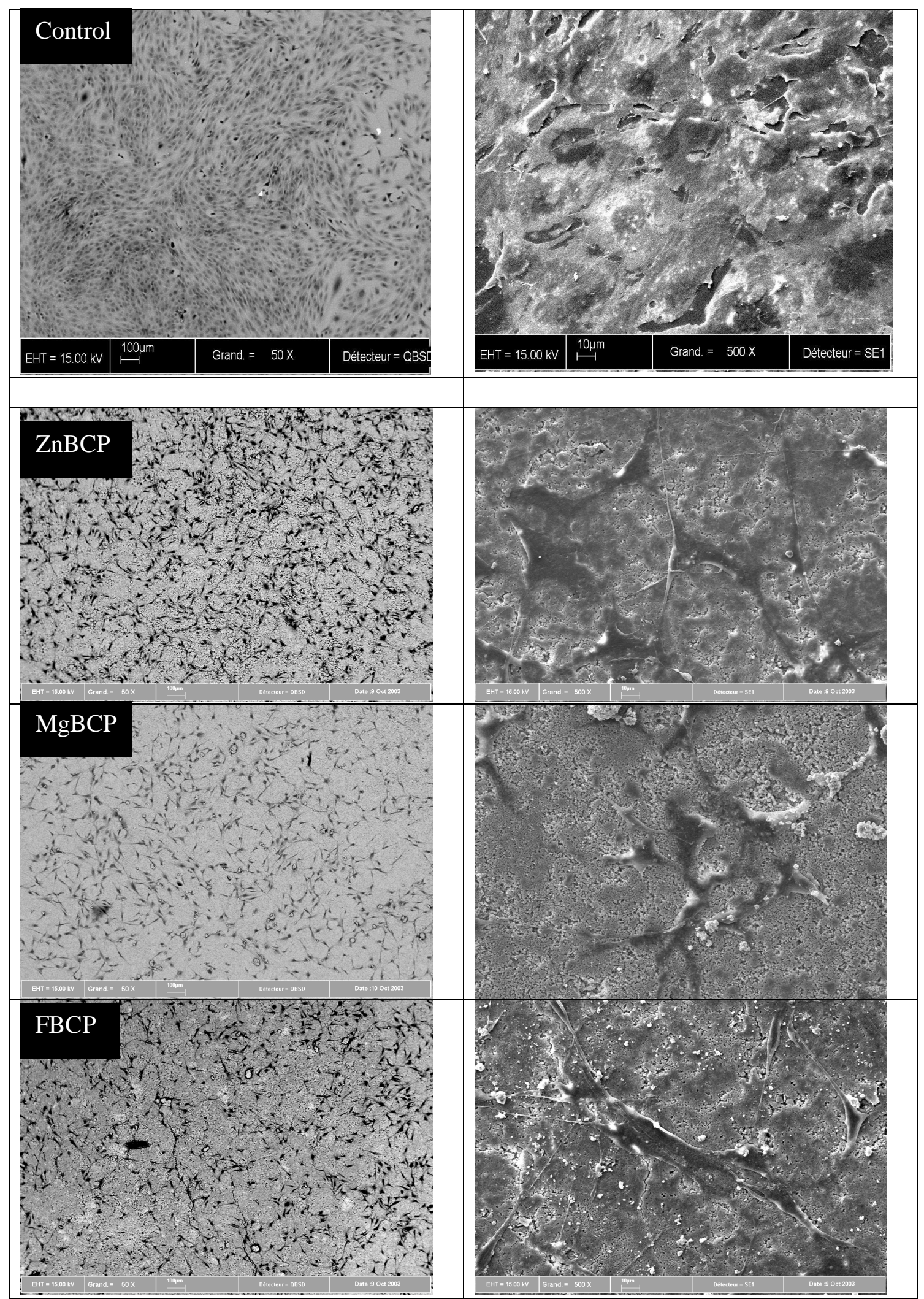


Table 1

\begin{tabular}{|c|c|c|}
\hline \multirow{2}{*}{} & \multicolumn{2}{|c|}{ Setting times (min) } \\
\cline { 2 - 3 } & $\mathrm{I}(\mathrm{min})$ & $\mathrm{F}(\mathrm{min})$ \\
\hline $\mathrm{Mg}-\mathrm{BCP}$ & $18 \pm 1$ & $41 \pm 2$ \\
\hline Zn-BCP & $15 \pm 2$ & $32 \pm 3$ \\
\hline F-BCP & $9 \pm 1$ & $26 \pm 2$ \\
\hline
\end{tabular}


Table 2.

\begin{tabular}{|c|c|c|}
\hline $\begin{array}{c}\text { Samples } \\
24 \text { setting }\end{array}$ & $\begin{array}{c}\text { Total porosity } \\
(\mathbf{\%})\end{array}$ & $\begin{array}{c}\text { Compressive strength } \\
\text { (MPa) }\end{array}$ \\
\hline Mg-BCP & $\begin{array}{c}66,02 \pm 2 \\
(22,78 \%>100 \mu \mathrm{m})\end{array}$ & $10 \pm 2$ \\
\hline $\mathbf{Z n - B C P}$ & $60.86 \pm 3$ & $13 \pm 2$ \\
$(14,23 \%>100 \mu \mathrm{m})$ & \\
\hline F-BCP & $51,23 \pm 3$ & $20 \pm 2$ \\
$(8,89 \%>100 \mu \mathrm{m})$ & \\
\hline
\end{tabular}


Figure 5

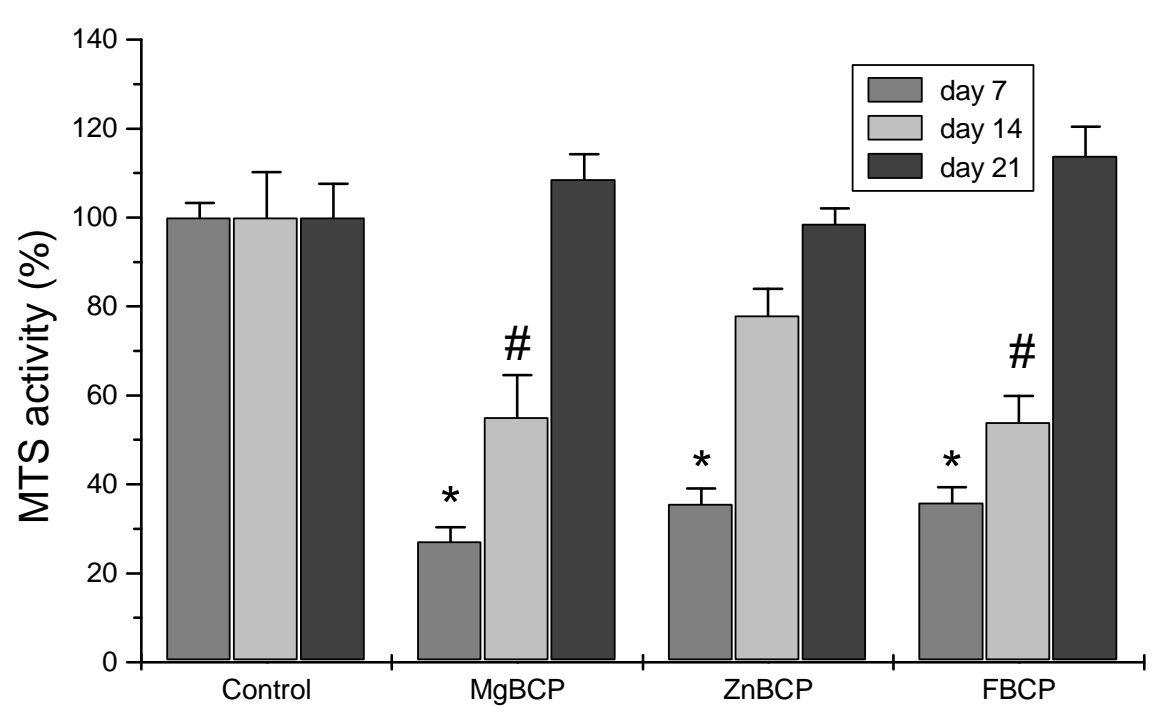


Figure 6

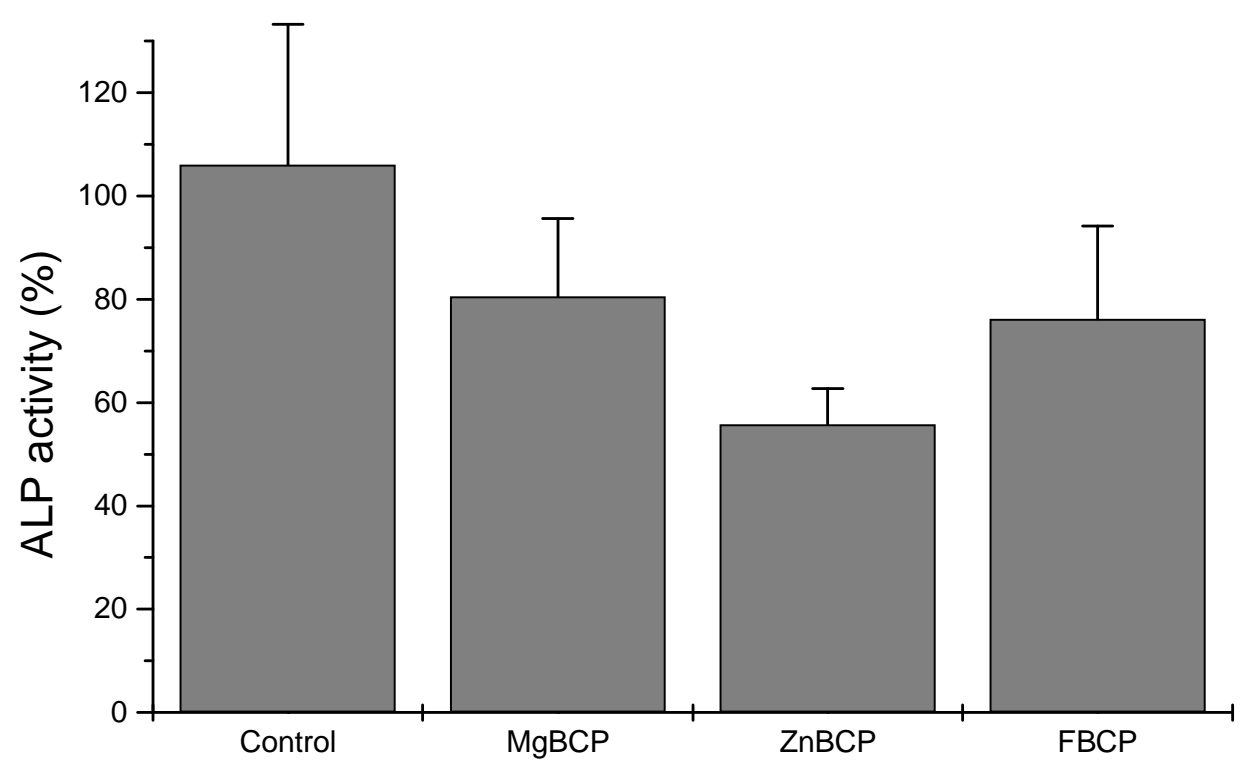




\section{LEGENDS}

Figure 1(a) X-ray diffraction pattern of different amorphous calcium phosphate salts

Figure 1(b) FTIR spectra of different amorphous calcium phosphate salts

Figure 2(b) X-ray diffraction pattern of cement (matrix + BCP) after $24 \mathrm{H}$ setting

Fig. 3 SEM pictures of the three cement samples after $24 \mathrm{H}$ setting. (a) $\mathrm{Mg}-\mathrm{BCP}$, (b) Zn-BCP, (c) F-BCP

Table 1 Setting times of cement samples prepared with a $\mathrm{L} / \mathrm{P}=0.36 \mathrm{ml} / \mathrm{g}$

Table 2 Compressive strength and porosity of cements after $24 \mathrm{H}$ setting

Figure 4 SEM observations of MC3T3-E1 cell morphology after 48h culture either in direct contact on Mg-BCP, Zn-BCP or F-BCP surface or on glass coverslips (control). Samples were observed using back-scattered electrons. Original magnification $\times 50, B A R=100 \mu \mathrm{m}$ (right panels). Samples were observed using secondary electrons. Original magnification $\times 500$; $\mathrm{BAR}=10 \mu \mathrm{m}$ (left panels).

Figure 5 MTS activity of MC3T3-E1 cells cultured in direct contact either on Mg-BCP, Zn-BCP or F-BCP surface or on plastic (control) for 7, 14 and 21 days. MTS activity was determined as indicated in materials and methods section. Results are expressed in relative MTS activity compared with control conditions. ${ }^{*} p<0.05$ and as compared to plastic

Figure 6 ALP activity of MC3T3-E1 cells cultured in direct contact either on $\mathrm{Mg}-\mathrm{BCP}, \mathrm{Zn}-\mathrm{BCP}$ or F-BCP surface or on plastic (control) for 21 days. ALP activity was measured as described in materials and methods section. Results are expressed in relative ALP activity compared with control conditions. 


\section{References}

1. LeGeros RZ. Properties of osteoconductive biomaterials: calcium phosphates. Clin Orthop Relat Res 2002(395):81-98.

2. LeGeros RZ, Chohayeb A, Shulman A. Apatitic calcium phosphates: possible resotrataive materials. J Dent Res 1982;61((Spec Iss): 343).

3. Brown WE, LC C. A new calcium phosphate setting cement. J Dent Res 1983;62:672.

4. Itoh S, Kikuchi M, Takakuda K, Koyama Y, Matsumoto HN, Ichinose S, et al. The biocompatibility and osteoconductive activity of a novel hydroxyapatite/collagen composite biomaterial, and its function as a carrier of rhBMP-2. J Biomed Mater Res 2001;54(3):445-53.

5. Khairoun I, Boltong MG, Driessens FC, Planell JA. Effect of calcium carbonate on the compliance of an apatitic calcium phosphate bone cement. Biomaterials 1997;18(23):1535-9.

6. Sorensen RG, Wikesjo UM, Kinoshita A, Wozney JM. Periodontal repair in dogs: evaluation of a bioresorbable calcium phosphate cement (Ceredex) as a carrier for rhBMP-2. J Clin Periodontol 2004;31(9):796-804.

7. del Real RP, Ooms E, Wolke JG, Vallet-Regi M, Jansen JA. In vivo bone response to porous calcium phosphate cement. J Biomed Mater Res A 2003;65(1):30-6.

8. Khairoun I, Magne D, Gauthier O, Bouler JM, Aguado E, Daculsi G, et al. In vitro characterization and in vivo properties of a carbonated apatite bone cement. J Biomed Mater Res 2002;60(4):633-42.

9. Rupprecht S, Merten HA, Kessler P, Wiltfang J. Hydroxyapatite cement (BoneSource) for repair of critical sized calvarian defects--an experimental study. J Craniomaxillofac Surg 2003;31(3):149-53. 
10. Smartt JM, Jr., Karmacharya J, Gannon FH, Ong G, Jackson O, Bartlett SP, et al. Repair of the immature and mature craniofacial skeleton with a carbonated calcium phosphate cement: assessment of biocompatibility, osteoconductivity, and remodeling capacity. Plast Reconstr Surg 2005;115(6):1642-50.

11. Silva RV, Camilli JA, Bertran CA, Moreira NH. The use of hydroxyapatite and autogenous cancellous bone grafts to repair bone defects in rats. Int J Oral Maxillofac Surg 2005;34(2):178-84.

12. Kuemmerle JM, Oberle A, Oechslin C, Bohner M, Frei C, Boecken I, et al. Assessment of the suitability of a new brushite calcium phosphate cement for cranioplasty - an experimental study in sheep. J Craniomaxillofac Surg 2005;33(1):37-44.

13. Sugawara A, Fujikawa K, Takagi S, Chow LC, Nishiyama M, Murai S. Histopathological and cell enzyme studies of calcium phosphate cements. Dent Mater J 2004;23(4):613-20.

14. Khairoun I, Boltong MG, Driessens FC, Planell JA. Effect of calcium carbonate on clinical compliance of apatitic calcium phosphate bone cement. J Biomed Mater Res 1997;38(4):356-60.

15. Khairoun I, Le Geros RZ, Daculsi G, Bouler JM, Gauthier O, J G, inventors; Macroporous, resorbavle and injectable calcium phosphate-based cements (MCPC) for bone repair, augmentation, regeneration, and osteoporosis treatment patent WO2005077049.

16. Sudo H, Kodama HA, Amagai Y, Yamamoto S, Kasai S. In vitro differentiation and calcification in a new clonal osteogenic cell line derived from newborn mouse calvaria. J Cell Biol 1983;96(1):191-8.

17. Citeau A, Guicheux J, Vinatier C, Layrolle P, Nguyen TP, Pilet P, et al. In vitro biological effects of titanium rough surface obtained by calcium phosphate grid blasting. Biomaterials 2005;26(2):157-65. 
18. Relic B, Guicheux J, Mezin F, Lubberts E, Togninalli D, Garcia I, et al. Il-4 and IL-13, but not IL-10, protect human synoviocytes from apoptosis. J Immunol 2001;166(4):2775-82.

19. Magne D, Bluteau G, Faucheux C, Palmer G, Vignes-Colombeix C, Pilet P, et al. Phosphate is a specific signal for ATDC5 chondrocyte maturation and apoptosis-associated mineralization: possible implication of apoptosis in the regulation of endochondral ossification. $\mathbf{J}$ Bone Miner Res 2003;18(8):1430-42.

20. Skrtic D, Antonucci JM, Eanes ED, Brunworth RT. Silica- and zirconia-hybridized amorphous calcium phosphate: effect on transformation to hydroxyapatite. J Biomed Mater Res 2002;59(4):597-604.

21. LeGeros RZ, Bleiwas CB, Retino M, Rohanizadeh R, LeGeros JP. Zinc effect on the in vitro formation of calcium phosphates: relevance to clinical inhibition of calculus formation. Am J Dent 1999;12(2):65-71.

22. Le Geros RZ, Mijares D, Park J, Chang XF, Khairoun I, Kijkowska R, et al. Amorphous calcium phosphates (ACP): Formation and stability. Key Engineering Materials 2005;284-286:710.

23. Fernandez E, Ginebra MP, Boltong MG, Driessens FC, Ginebra J, De Maeyer EA, et al. Kinetic study of the setting reaction of a calcium phosphate bone cement. J Biomed Mater Res 1996;32(3):367-74.

24. Ginebra MP, Fernandez E, De Maeyer EA, Verbeeck RM, Boltong MG, Ginebra J, et al. Setting reaction and hardening of an apatitic calcium phosphate cement. J Dent Res 1997;76(4):905-12.

25. Li R, Clark AE, Hench LL. An investigation of bioactive glass powders by sol-gel processing. J Appl Biomater 1991;2(4):231-9. 
26. Bermudez O, Boltong MG, Driessens FCM, JA P. Development of some calcium phosphate cements from combinations of $\alpha-\mathrm{TCP}, \mathrm{MCPM}$, and CaO. J Mater Sci Med 1994;3:160-163.

27. Le Geros RZ. Apatites in biological systems. Prog Crystal Growth Charact 1981;4:1-45.

28. Miyamoto Y, Ishikawa K, Takechi M, Yuasa M, Kon M, Nagayama M, et al. Non-decay type fast-setting calcium phosphate cement: setting behaviour in calf serum and its tissue response. Biomaterials 1996;17(14):1429-35.

29. Kurashina K, Kurita H, Hirano M, Kotani A, Klein CP, de Groot K. In vivo study of calcium phosphate cements: implantation of an alpha-tricalcium phosphate/dicalcium phosphate dibasic/tetracalcium phosphate monoxide cement paste. Biomaterials 1997;18(7):539-43.

30. Craig SW, Johnson RP. Assembly of focal adhesions: progress, paradigms, and portents. Curr Opin Cell Biol 1996;8(1):74-85.

31. Ben-Ze'ev. Cytoskeletal and adhesion proteins as tumor suppressors. Curr Opin Cell Biol 1997;9:99-108.

32. Anselme K, Linez P, Bigerelle M, Le Maguer D, Le Maguer A, Hardouin P, et al. The relative influence of the topography and chemistry of TiAl6V4 surfaces on osteoblastic cell behaviour. Biomaterials 2000;21(15):1567-77.

33. Wennerberg A, Albrektsson T, Andersson B. Bone tissue response to commercially pure titanium implants blasted with fine and coarse particles of aluminum oxide. Int J Oral Maxillofac Implants 1996;11(1):38-45.

34. Deligianni DD, Katsala ND, Koutsoukos PG, Missirlis YF. Effect of surface roughness of hydroxyapatite on human bone marrow cell adhesion, proliferation, differentiation and detachment strength. Biomaterials 2001;22(1):87-96. 
35. Wagner EF, Karsenty G. Genetic control of skeletal development. Curr Opin Genet Dev 2001;11(5):527-32. 